\title{
DEWAN PENGAWAS SYARIAH DAN PROFESIONALISME SUMBER DAYA MANUSIA
}

\author{
H. Rahman Ambo Masse \\ Institut Agama Islam Negeri Parepare \\ rahman.ambōyahoo.co.id
}

\begin{abstract}
Sharia Supervisory Board (DPS) is one of the most important part in the system of Islamic financial and banking institutions in Indonesia. The existence of DPS is recognized based on applicable laws and regulations. The existence of DPS in sharia financial institutions and sharia banking aims to oversee sharia principles that must be implemented in real terms in the contract system and transactions in Islamic financial and banking institutions. Empirically, the recognition of legislation on the existence of DPS has not been fully implemented by Islamic financial and banking institutions. In fact, recommendations regarding the findings of sharia principles violations in the contract system and transactions in sharia financial and banking institutions often receive a response from the board of directors. Therefore, the most important indicator that DPS must have is the professionalism of its human resources. Competence is a determinant factor in recruiting DPS. These competencies include aspects of mastery of figh muamalah theories, competency in reading financial statements, and competencies in the field of engagement law.
\end{abstract}

\section{Keywords: Sharia Supervisory Board, Financial Institutions, Islamic Banking, Human Resources, Competence.}

\begin{abstract}
Abstrak: Dewan Pengawas Syariah (DPS) bagian terpenting dalam sistem lembaga keuangan dan perbankan syariah di Indonesia. Eksistensi DPS diakui berdasarkan peraturan perundang-undangan yang berlaku. Keberadaan DPS pada lembaga keuangan syariah dan perbankan syariah bertujuan mengawasi prinsip-prinsip syariah yang harus terimplementasi secara riil dalam sistem akad dan transaksi pada lembaga keuangan dan perbankan syariah. Secara empiris, pengakuan peraturan perundang-undangan terhadap eksistensi DPS belum sepenuhnya dijalankan oleh lembaga keuangan dan perbankan syariah. Faktanya, rekomendasi-rekomendasi terkait temuan pelanggaran prinsip syariah dalam sistem akad dan transaksi pada lembaga keuangan dan perbankan syariah seringkali kurang mendapat respon dari dewan direksi. Karena itu, Indikator terpenting yang harus dimiliki DPS adalah profesionalisme sumber daya manusianya. Kompetensi menjadi faktor determinan dalam merekrut DPS. Kompetensi tersebut mencakup aspek penguasaan akan teoriteori fikih muamalah, kompetensi membaca laporan keuangan, dan kompetensi di bidang hukum perikatan.
\end{abstract}


Kata kunci: Dewan Pengawas Syariah, Lembaga Keuangan, Perbankan Syariah, Sumber Daya Manusia, Kompetensi.

\section{PENDAHULUAN}

\section{A. Latar Belakang Masalah}

Perkembangan perbankan

syariah di Indonesia sangat progresif dan signifikan. Dari tahun ke tahun, pertumbuhan bank syariah di Indonesia mengalami peningkatan yang tinggi. Pada tahun 2018, tercatat sudah ada 13 bank umum syariah, dan 22 bank umum yg membuka Unit Usaha Syariah (UUS), dan 168 bank Bank Perkreditan Rakyat Syariah (BPRS), sehingga total jaringan kantor perbankan syariah mencapai 2.881 kantor dengan total asset sebesar 423.944 Triliun Rupiah. ${ }^{\mathrm{i}}$

Menjamurnya perbankan syariah di Indonesia tidak terlepas dari payung hukum berupa peraturan perundang-undangan dan peraturan pemerintah yang mendukung dan memberikan kepastian hukum terhadap beroperasinya perbankan syariah. Hal itu dapat dilihat dengan diundangkannya Undang-undang No. 21 Tahun 2008 tentang Perbankan
Syariah yang secara tegas memberikan payung hukum dan pengakuan akan eksistensi perbankan syariah di Indonesia. Kehadiran perbankan syariah juga memiliki andil yang signifikan dalam menanggulangi tingkat pengangguran terbuka di Indonesia dengan merekrut ribuan sarjana dari berbagai disiplin ilmu.

Pesatnya perkembangan bank sayriah tidak disertai dengan kompetensi sumber daya manusianya. Data hasil penelitian menunjukkan bahwa kebutuhan lembaga keuangan syariah, baik perbankan syariah, asuransi syariah, bank perkreditan rakyat syariah, BMT, dan reksadana syariah terhadap sumber daya manusia yang memahami aspek-aspek ekonomi syariah dan hukum ekonomi syariah masih cukup tinggi.

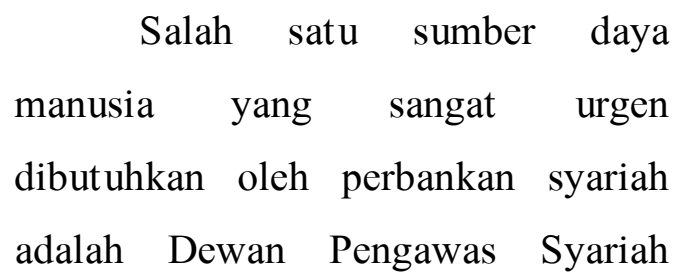


(DPS). Lembaga ini yang mengawasi dan menjustifikasi akad dan produk perbankan syariah agar sesuai dengan prinsip-prinsip syariah sebagaimana yang diamanahkan oleh peraturan pemerintah dan fatwa Dewan Syariah Nasional (DSN) Majelis Ulama Indonesia. secara formal-yuridis, kehadiran DPS sangat dibutuhkan oleh perbankan syariah, namun secara faktual-empiris kehadiran DPS pada perbankan syariah kurang legitimed, rekomendasi-rekomendasi yang dihasilkan seringkali kurang diperhatikan oleh penentu kebijakan pada perbankan syariah.

\section{B. Rumusan Masalah}

Berdasarkan latar belakang di atas, maka persoalan pokok yang dibahas dalam makalah ini adalah bagaimana peran dewan pengawas syariah dalam mengawasi perbankan syariah di Indonesia yang diurai dalam sub masalah sebagai berikut:

1. Bagaimana kedudukan dewan pengawas syariah dalam sistem hukum di Indonesia?
2. Bagaimana tantangan dewan pengawas syariah dalam mengawasi perbankan syariah?

3. Bagaimana metodologi penetapan fatwa dewan syariah nasional majelis ulama Indonesia?

\section{PEMBAHASAN}

\section{A. Kedudukan Dewan Pengawas} Syariah dalam Sistem Hukum di Indonesia

Dewan Syariah Nasional (DSN) merupakan sebuah institusi di bawah struktur Majelis Ulama Indonesia yang wacana pembentukannya telah dibicarakan pada dekade tahun 1990-an, ketika MUI melakukan lokakarya yang membahas tentang bunga bank yang berakhir pada kesimpulan kecenderungan mempersamakan bunga bank dengan riba. Pada lokakarya yang membahas tentang reksadana syariah diselenggarakan di Jakarta pada 29-30 Januari 1997, salah satu rekomendasinya adalah pembentukan Dewan Syariah Nasional 
(DSN) yang kemudian gagasan itu dimantapkan pada pertemuan tanggal 14 Oktober 1997. Namun secara resmi DSN-MUI terbentuk pada tahun 1998 yang secara structural berada di bawah Majelis Ulama Indonesia melengkapi lembaga-lembaga lainnya yang ada sebelumnya.

Dasar pemikiran dan latarbelakang pembentukan DSN-MUI bertujuan untuk efisiensi dan koordinasi para ulama dalam menanggapi isu-isu yang berhubungan dengan masalah ekonomi dan keuangan. Selain itu, DSN diharapkan dapat berperan sebagai pengawas, pengarah, dan pendorong nilai-nilai dan prinsip-prinsip ajaran Islam di bidang ekonomi dan keuangan. Karena itu, secara kelembagaan, DSN-MUI berperan proaktif dalam menanggapi dan merumuskan solusi terhadap perkembangan social kemasyarakatan di bidang ekonomi dan keuangan. ${ }^{\text {ii }}$ (Nafis, 81: 2011). Sebagaimana peran MUI sebagai otoritas lembaga yang mengeluarkan fatwa dan nasihat kepada pemerintah dan umat Islam dalam masalah yang berhubungan dengan persoalan keagamaan dan kemaslahatan bangsa serta menjaga persatuan umat. Fatwa merupakan alternative hukum yang diperlukan untuk memberi jawaban tentang masalah kehidupan dari perspektif agama, baik untuk konsumsi masyarakat maupun untuk kepentingan pemerintah. (Nafis, 81; 2011)

Secara de fakto dan de jure, kewenangan DSN-MUI diakui oleh peraturan perundang-undangan di Indonesia sebagai lembaga yang merumuskan prinsip-prinsip syariah dalam bidang ekonomi dan keuangan syariah di Indonesia. Legitimasi dan kedudukan fatwa DSN-MUI dalam mengatur aspek ketentuan prinsip syariah pada lembaga keuangan syariah (LKS) baik bank maupun nonbank diakui dalam sistem perundangundangan di Indonesia. yaitu:

1. UU No. 21 Tahun 2008 Tentang Perbankan Syariah Pasal 1 angka (12), meskipun secara implisit 
UUPS tidak menyebutkan secara redaksional DSN-MUI, namun secara eksplisit dipahami bahwa yang memiliki kewenangan mengeluarkan fatwa ketentuan prinsip syariah terhadap lembaga keuangan syariah adalah DSNMUI sebagai salah satu komisi yang menangani fatwa di bidang ekonomi dan keuangan syariah pada Mejelis Ulama Indonesia.

2. Surat Keputusan Direksi Bank Indonesia Nomor 23/34/1999, Pasal $31^{\mathrm{iii}}$

3. Undang-Undang Nomor 40 Tahun 2007 Tentang Perseroan Terbatas Pasal $109^{\text {iv }}$

Untuk menjalankan tugas dan fungsi organisasi, DSN dibantu oleh Badan Pelaksana Harian Dewan Syariah Nasional (BPH-DSN) Struktur keanggotaan DSN dan BPHDSN dibentuk dan ditunjuk oleh Majelis Ulama Indonesia (MUI). Secara teknis, Pengurus BPH-DSN menjalankan sebagian tugas-tugas DSN-MUI. Keanggotaan BPH-DSN terdiri dari para ahli hukum Islam dan pakar bidang muamalah (bidang ekonomi dan keuangan syariah) yang bertanggung jawab langsung kepada Pengurus Pleno DSN-MUI. Sedangkan keanggotaan DSN-MUI terdiri dari ahli hukum Islam, pakar bidang muamalah dan ekonomi syariah, dan praktisi, serta akademisi yang berkaitan dengan bidang muamalah dan ekonomi syariah. Masa bakti keanggotaan DSN-MUI 4 tahun dan dapat dipertimbangkan untuk diangkat kembali selama dua periode. ${ }^{\mathrm{v}}$

Tugas utama DSN-MUI adalah menggali, mengkaji, dan merumuskan prinsip-prinsip hukum Islam dalam bentuk fatwa untuk dijadikan pedoman dalam kegiatan operasional transaksi lembaga keuangan syariah, serta mengawasi implementasi fatwafatwa dalam ranah ekonomi dan keuangan syariah. Karena itu, DSNMUI memiliki otoritas:

1. Mengeluarkan fatwa yang mengikat Dewan Pengawas Syariah (DPS) di masingmasing lembaga keuangan 
syariah dan menjadi dasar tindakan hukum pihak terkait.

2. Mengeluarkan fatwa untuk kepentingan institusi terkait, seperti Bank Indonesia, Otoritas Jasa Keuangan, Kementerian Keuangan, dan BAPEPAM.

3. Merekomendasikan dan menghentikan anggota perwakilan DPS pada lembaga keuangan syariah.

4. Mengundang para pakar untuk menjelaskan dan mengurai suatu masalah yang berkaitan dengan pembahasan ekonomi syariah.

5. Memberikan teguran kepada lembaga keuangan syariah untuk menghentikan penyimpangan fatwa-fatwa DSN-MUI

6. Merekomendasikan kepada institusi terkait untuk mengambil kebijakan dan tindakan apabila teguran tidak diindahkan. ${ }^{\mathrm{vi}}$
Penetapan fatwa DSN-MUI mengikuti pedoman dan panduan yang telah ditetapkan oleh Komisi Fatwa Majelis Ulama Indonesia ${ }^{\text {vii }}$ berdasarkan pedoman dan prosedur fatwa MUI, bahwa setiap masalah yang dibahas di Komisi Fatwa, termasuk fatwa bidang ekonomi dan keuangan syariah, harus didasarkan pada al-Qur'an, Sunnah, Ijma, dan Qiyas. Selain itu, sebelum fatwa diputuskan harus meneliti secara seksama pendapat para imam Mazhab beserta dalil-dalilnya dari kitab yang mu'tabarah pada MUI. Metode istinbat hukum yang diterapkan oleh MUI adalah dengan mengkompromikan metode istinbăt organisasi Nahdlatul Ulama dan Muhammadiyah. Hal ini terlihat dari prosedur penetapan fatwa yang langsung merujuk kepada al-Qur'an, sunah, dan pendekatan tarjih yang merupakan ciri pendekatan Majelis Tarjih Muhammadiyah. Sedangkan penuluran dan investigasi pendapat imam mazhab, kemudian mengkompromikan dan melakukan 
pendekatan ilhāqi (analogi) suatu masalah dengan pedanannya merupakan ciri pendekatan istinbät Lembaga Bahtsul Masail Nahdlatul Ulama. ${ }^{\text {viii }}$ Secara formal, DSN-MUI menggunakan empat sumber hukum yang disepakati oleh para ulama Sunni, yaitu al-Qur'an, Hadis, Ijma, dan Qiyas. Secara operasional, DSNMUI juga sering menggunakan sumber hukum yang diperselisihkan, yaitu maṣlaḥah mursalah, istiḥsān, sadd alzari'ah, dan 'urf. Kecenderungan penggunaan sumber hukum yang diperselisihkan ini dapat dilihat pada dasar hukum penetapan fatwa DSNMUI di bidang ekonomi dan keuangan syariah.

Dewan Pengawas Syariah merupakan perwakilan DSN-MUI yang di tempatkan di Lembaga Keuangan Syariah (LKS), baik bank maupun non-bank. Ketentuan tentang penempatan Dewan Pengawas Syariah (DPS) pada lembaga keuangan syariah diatur oleh UU Nomor 40 Tahun 2007 Tentang Perseroan Terbatas Pasal 109 dan UU No. 21 Tahun 2008 Tentang
Perbankan Syariah Pasal 32 ayat (1). ${ }^{\text {ix }}$ DPS memiliki tiga peran penting, yaitu, Pertama, sebagai penasihat dan pemberi saran kepada dewan direksi, pimpinan unit usaha syariah, dan pimpinan kantor cabang syariah mengenai hal-hal yang berkaitan dengan kesesuaian operasional lembaga keuangan dengan prinsipprinsip syariah. Kedua, sebagai pengawas yang memastikan bahwa sistem operasional lembaga keuangan syariah tunduk pada ketentuan fatwa DSN-MUI sebagai otoritas penentuan prinsip syariah dalam bidang ekonomi dan keuangan syariah. Ketiga, sebagai mediator antara lembaga keuangan syariah dengan DSN-MUI dalam merekomendasikan pengembangan produk dan layanan jasa lembaga keuangan yang memerlukan fatwa DSN-MUI.

Tugas dan fungsi DPS diatur dalam Peraturan Bank Indonesia Nomor 11/33/PBI/2009 Tentang Pelaksanaan Good Corporate Governance Bagi Bank Umum Syariah dan Unit Usaha Syariah Pasal 
47, yaitu, tugas dan tanggung jawab Dewan Pengawas Syariah adalah, Pertama, memberi nasihat dan saran kepada Direksi. Kedua. mengawasi kegiatan Bank agar sesuai dengan Prinsip Syariah. Pelaksanaan tugas dan tanggung jawab DPS meliputi: (a) Menilai dan memastikan pemenuhan Prinsip Syariah atas pedoman operasional dan produk yang dikeluarkan Bank. (b) Mengawasi proses pengembangan produk baru Bank agar sesuai dengan fatwa Dewan Syariah Nasional-Majelis Ulama Indonesia. (c) Meminta fatwa kepada Dewan Syariah Nasional-Majelis Ulama Indonesia untuk produk yang belum ada fatwanya. (d) Melakukan review secara berkala atas pemenuhan Prinsip Syariah terhadap mekanisme penghimpunan dana dan penyaluran dana serta pelayanan jasa Bank. (e) Meminta data dan informasi terkait dengan aspek syariah dari satuan kerja Bank dalam rangka pelaksanaan tugasnya. ${ }^{\mathrm{x}}$

Ketentuan tugas DPS sebagaimana yang tercantum dalam anggaran dasar dan rumah tangga DSN-MUI, yaitu, Pertama, wajib mengikuti dan tunduk pada fatwa DSN-MUI. Kedua, merumuskan permasalahan yang memerlukan pengesahan DSN. Ketiga, Melaporkan kegiatan usaha dan perkembangan lembaga keuangan syariah yang diawasinya kepada DSN sekurangkurangnya sekali dalam setahun. Sedangkan komposisi anggota DPS terdiri dari ahli syariah, praktisi, dan pakar hukum ekonomi dan keuangan syariah. Anggota DPS bersifat independen dan tidak dapat diintervensi. Struktur anggota DPS terdiri dari tiga orang. Satu di antaranya ditunjuk menjadi pimpinan DPS.

Salah satu tugas dan tanggung jawab DPS sebagaimana dicantumkan dalam Peraturan Bank Indonesia (PBI) adalah melakukan review secara berkala atas pemenuhan Prinsip Syariah terhadap mekanisme penghimpunan dana dan penyaluran dana serta pelayanan jasa Bank. Karena itu, Mekanisme pengawasan 
yang dilakukan oleh DPS terkait penerapan dan ketundukan lembaga keuangan syariah terhadap prinsipprinsip syariah adalah dengan melakukan uji petik secara acak terhadap akad-akad yang menjadi alas transaksi keuangan pada lembaga keuangan syariah. Melalui uji petik dapat diketahui ada tidaknya pelanggaran terhadap prinsip syariah itu.

Perkembangan lembaga keuangan syariah, khususnya perbankan syariah yang terus mengalami perkembangan secara signifikan menuntut kesiapan sumber daya manusia. Sumber daya manusia merupakan aktor terpenting bagi setiap organisasi dalam perekonomian global yang berbasis pengetahuan dan keterampilan. Karena itu, kunci untuk menjaga suatu organisasi itu dapat survive dan memiliki tingkat output ekonomi yang tinggi adalah bagaimana sebuah organisasi dapat mengendalikan dan memanfaatkan human capital yang dimilikinya.
Para ahli berbeda pandangan dalam mendefinisikan kata kompetensi:

1. Kompetensi dapat didefinisikan sebagai pengetahuan, keterampilan, kemampuan dan karakterisitik lainnya, seperti sikap, perilaku dan kemampuan fisik yang dimiliki oleh seseorang dan sangat diperlukan untuk menjalankan sebuah aktifitas dalam sebuah konteks bisnis tertentu.

2. Kompetensi adalah pengetahuan, keterampilan, karakteristik kepribadian, dan sikap yang memungkinkan karyawan untuk menjalankan tugas-tugas dan peran-peran dalam pekerjaannya.

3. Kompetensi dapat diartikan sebagai kemampuan seseorang yang dapat terobservasi yang mencakup atas pengetahuan, keterampilan dan sikap dalam menyelesaikan suatu pekerjaan 
atau tugas sesuai dengan performen yang ditetapkan. $^{\mathrm{xi}}$

Dari berbagai definisi di atas, dapat dikatakan bahwa kompetensi merupakan perpaduan pengetahuan, keterampilan, sikap, dan karakteristik pribadi lainnya yang diperlukan untuk mencapai keberhasilan dalam sebuah pekerjaan, yang dapat diukur dengan menggunakan standar yang telah disepakati, dan yang dapat ditingkatkan melalui pelatihan dan pengembangan. ${ }^{\text {xii }}$

\section{Secara}

operasional,

kompetensi dapat diklasifikasikan menjadi dua bagian, yaitu, pertama, kompetensi inti. Kompetensi ini terkait dengan pemahaman terhadap visi, misi, dan nilai-nilai organisasi atau instansi. Karena itu, setiap perusahaan atau instansi memiliki prinsip-prinsip yang menjadi acuan yang dapat diterjemahkan ke dalam prilaku stakholdernya. kedua, kompetensi teknis. Kompetensi ini mencakup pengetahuan dan keterampilan yang sangat spesifik dan berhubungan erat dengan jenis pekerjaan pada suatu jabatan dalam suatu organisasi atau instansi.

Sumber daya manusia lembaga keuangan syariah harus memiliki karakter building yang berbeda dengan lembaga keuangan konvensional. Nilai-nilai Islam harus menjadi way of life dan menjadi kerangka dasar dalam sistem kerja perusahaan. Budaya kapatilasme-materialis yang menjadi bagian dari sistem kerja lembaga keuangan konvensional harus diminimalisir. Kecenderungan lembaga keuangan syariah berpandangan konvensional, karena pada umumnya sumber daya manusia yang direkrut bersumber dari lembaga keuangan konvensional. Pesatnya perkembangan lembaga keuangan syariah berbanding terbalik dengan sumber daya manusia yang memiliki karakter syariah. Secara kualitas maupun kuantitas, kebutuhan lembaga keuangan syariah terhadap sumber daya manusia masih tinggi seiring perkembangan lembaga keuangan syariah yang sangat progresif, 
sementara out put perguruan tinggi yang mengajarkan ekonomi syariah belum maksimal mengisi peluang berkarir di lembaga keuangan syariah. Karena itu, lembaga keuangan syariah merekrut sumber daya manusianya dari lembaga keuangan konvensional yang ditraining singkat. Akibatnya, presepsi masyarakat terhadap lembaga keuangan syariah tidak berbeda dengan lembaga keuangan konvensional.

Pergerakan lembaga keuangan syariah, utamanya perbankan syariah yang sangat progresif menuntut peran ulama melalui institusi DSN-MUI dan DPS untuk lebih intensif dalam menghadapi problematika di bidang ekonomi dan keuangan syariah yang tingkat kompleksitasnya juga semakin tinggi. Ciri khas perbankan syariah, sebagai bank yang berbasis pada label Islam menjadikan bank syariah sangat sensitive terhadap isu-isu syariah. Karena itu, kompetensi DSN dan DPS harus terjamin. ${ }^{\text {xiii }}$ Anggota DSN dan DPS haruslah ulama yang memiliki pemahaman dalam bidang ekonomi.
Sedangkan anggota direksi haruslah seorang ahli ekonomi dan keuangan yang paham akan hukum Islam.

Dewan Syariah Nasional dan Dewan Pengawas Syariah merupakan lembaga yang digawangi oleh para ulama berintegritas. Karena itu, terdapat persyaratan penting yang harus dimiliki oleh anggota lembaga pengawas dalam konsep fikih, yaitu. Pertama, memiliki integritas dan konsisten mengikuti ketentuan syariat. $^{\text {xiv }}$ Pengawasan lembaga keuangan apalagi berlabelkan syariah adalah bentuk pengabdian kepada sang Khaliq. Konsepsi pengamalan ajaran agama dalam Islam terdiri dari aspek akidah, ibadah, dan akhlak. Bermuamalah atau menerapkan prinsip-prinsip agama dalam kegiatan ekonomi dan keuangan adalah bagian dari pengamalan ajaran agama. Kedua, harus memenuhi persyaratan sebagai pengawas, yaitu, (a) mampu untuk menegakkan amar ma'ruf nahi mungkar. (b) memiliki komptensi di bidangnya. (c) memiliki kualitas iman dan integritas yang tinggi. ${ }^{\mathrm{xv}}$ Jabatan 
sebagai pengawas bidang syariah merupakan amanah yang menuntut keberanian mengatakan yang benar dan yang batil adalah salah. Karena itu, untuk memastikan adanya pelanggaran atau dugaan penyimpangan akan prinsip syariah pada perbankan syariah dibutuhkan kompetensi dan keahlian, yaitu paham akan hukum, baik hukum Islam maupun hukum perikatan, paham membaca laporan keuangan, dan berani bertindak tegas. Ketiga, Memiliki kualifikasi syarat-syarat berfatwa. Yaitu paham akan maksud dalil (al-Qur'an dan sunah), mengetahui penentuan kesahihan hadis, paham bahasa Arab, dan memiliki akhlak terpuji dan fatanah. Keempat, Memiliki kompetensi yang dibutuhkan pada perbankan syariah. ${ }^{\text {xvi }}$ Diantaranya, Menguasai dan memahami fatwa-fatwa yang dikeluarkan oleh lembaga resmi. Memahami regulasi berkaitan dengan perbankan syariah. Mampu berkomunikasi dan bernegosiasi secara baik dan santun. Dan terus mengembangkan kemampuan diri.

B. Tantangan Dewan Pengawas Syariah dalam Mengawasi Perbankan Syariah

Lembaga Dewan Pengawas Syariah disebutkan dalam UU Nomor 21 Tahun 2008 Tentang Perbankan Syariah sebagai pihak terafiliasi. Pengertian pihak terafiliasi adalah pihak yang memberikan jasanya kepada bank syariah atau unit usaha syariah pada bank konvensional.

Dewan Pengawas Syariah memiliki peran dan fungsi yang sangat strategis dalam menjamin perbankan syariah tetap konsisten menerapkan prinsip syariah dalam kegiatan operasional perbankan. Penerapan prinsip syariah merupakan amanah ketentuan perundang-undangan, utamanya UU Perbankan Syariah Pasal 2 yang menyebutkan bahwa "Perbankan Syariah dalam melakukan kegiatan usahanya berasaskan prinsip syariah, demokrasi ekonomi, dan prinsip kehati-hatian". Karena itu, 
DPS memiliki peran dan kewenangan untuk memastikan penerapan asas prinsip syariah. Apabila kewenangan tersebut tidak dilaksanakan secara professional sesuai aturan perundangan, maka diancam dengan sanksi Pidana sebagaimana diatur dalam UU Perbankan Syariah Pasal 64. ${ }^{\mathrm{xvii}}$

Kegiatan organisasi tidak selamanya berjalan sesuai dengan standar operasional. Terdapat kendala yang mungkin dihadapi DSN-MUI dan DPS dalam melaksanakan tugas dan kewenangannya. Kendala-kendala itu sebagaimana berikut:

1. Sulitnya mendapatkan sumber daya manusia yang menguasai bidang hukum Islam dan ahli dibidang ekonomi dan keuangan. ${ }^{\text {xviii }}$ Dinamika hukum ekonomi dan keuangan terus berkembang seiring perkembangan model transaksi keuangan. Perbankan syariah sebagai lembaga yang menawarkan jasa terhadap pihak lain juga harus mengikuti kecenderungan transaksi yang diinginkan nasabahnya. Perbankan syariah harus siap menyediakan layanan produk dan jasa yang ekspektabel terhadap keinginan nasabah. Salah satu cirri perbankan syariah adalah setiap produk transaksi keuangan harus didasarkan atas akad yang jelas. Kecenderungan nasabah terhadap jenis dan produk baru harus didasarkan atas akad yang sesuai dengan prinsip syariah dan hukum Islam. Karena itu, para anggota DSN-MUI dan DPS harus memiliki kualifikasi seorang mujtahid. Dengan kompetensi seperti itu, memungkinkan penyelesaian persoalan hukum secara cepat dan tetap konsisten terhadap penerapan prinsip syariah.

2. Kurangnya respon terhadap keputusan dan rekomendasi DPS. ${ }^{\text {xix }}$ Peraturan perundang-undangan mengatur bahwa DPS harus melakukan rapat sekali dalam sebulan. Tingkat kompetensi sumber daya manusia perbankan syariah sangat bervariasi, dan 
umumnya mereka tidak memahami secara mendalam hukum Islam dan hukum ekonomi Islam. Atas dasar itu, implementasi prinsip syariah rawan terjadi penyimpangan dalam akad-akad perbankan. Sistem pengawasan yang sentralistik sebagaimana umumnya pada bank umum syariah membuat keputusan DPS menjadi lambat untuk secepatnya diakses oleh direksi di kantor cabang. Indikasi lain, jajaran DPS juga jarang turun langsung mengunjungi kantor-kantor cabang untuk melakukan pengawasan secara rutin dan berkala. Padahal DPS memiliki kewenangan yang sangat fundamental, yaitu harus memastikan bahwa transaksi keuangan perbankan syariah tidak menyimpang dari ketentuan prinsip syariah sebagaimana fatwa-fatwa DSN-MUI. Namun terkadang hasil keputusan yang tertuang dalam risalah rapat kurang mendapat respon dari direksi dan pengambil kebijakan
3. Terbatasnya kewenangan $\operatorname{DPS}^{\mathrm{xx}}$. Peraturan Bank Indonesia mengatur fungsi dan kewenangan DPS, yaitu sebagi pemberi saran kepada direksi. Karena itu, kewenangan DPS hanya sebagai pemberi opini syariah. Kedudukan fatwa atau opini syariah yang dikeluarkan oleh DPS bersifat sementara. Opini syariah harus diusulkan melalui Badan Pengurus Harian DSN-MUI untuk dibahas dalam musyawarah pleno-DSN-MUI. Namun fatwa yang dihasilkan DSN-MUI tidak bersifat mengikat sebelum dipositivasi kedalam peraturan bank Indonesia. Fatwa DSN-MUI juga tidak semuanya diserap menjadi peraturan perundangundangan, sebab fatwa tersebut harus melalui Komite Perbankan Syariah (KPS). ${ }^{\mathrm{xxi}} \quad$ Struktur keanggotaan KPS beranggotakan unsur-unsur dari Bank Indonesia, Kementerian Agama, dan tokoh masyarakat yang memiliki keahlian dibidang hukum Islam. Keterbatasan kewenangan DPS 
yang hanya dapat mengeluarkan opini syariah yang bersifat sementara, sehingga seringkali opini tersebut agak lambat diakses oleh direksi. Pada kantor cabang, mekanisme penentuan legalitas produk baru yang ditawarkan kepada nasabah atau ketika ditemukan dugaan pelanggaran prinsip syariah, maka kasus itu diserahkan kepada divisi complain syariah untuk selanjutnya direkomendasikan kepada DPS terkait permintaan opini syariah.

Tugas dan tanggung jawab DPS sebagaimana diatur dalam Peraturan Bank Indonesia (PBI) Nomor 11/3/PBI/2009 Tentang Bank Umum Syariah Pasal $35^{\mathrm{xxii}}$ junto Peraturan Bank Indonesia (PBI) Nomor 11/33/PBI/2009 Tentang Pelaksanaan Good Corporate Governance bagi Bank Umum Syariah dan Unit Usaha Syariah Pasal 47 adalah sebagai pemberi nasihat dan saran kepada Direksi serta pengawas prinsip syariah pada kegiatan Bank. Pelaksanaan tugas dan tanggung jawab Dewan Pengawas Syariah antara lain: (a) Menilai dan memastikan pemenuhan Prinsip Syariah atas produk yang dikeluarkan Bank. (b) Mengawasi proses pengembangan produk baru Bank agar sesuai dengan fatwa Dewan Syariah Nasional-Majelis Ulama Indonesia (DSN-MUI). Berdasarkan peraturan Bank Indonesia tersebut, maka kewenangan DPS dalam mengawasi pelaksanaan prinsip syariah menjadi legitimed dan hasil keputusannya memiliki kekuatan hukum yang dapat dipertanggung jawabkan.

\section{Metodologi Penetapan Hukum DSN-MUI}

Fatwa DSN-MUI memiliki peran signifikan dalam penentuan aspek kesyari'ahan produk ekonomi dan keuangan syariah di Indonesia. Dalam kegiatan ekonomi yang sangat dipengaruhi oleh kondisi ruang dan waktu, posisi fatwa sebagai referensi hukum sangat diperlukan untuk memastikan lembaga keuangan syariah, baik bank maupun non-bank 
konsisten terhadap prinsip syariah (syariah compliance). Konsistensi lembaga keuangan syariah terhadap aspek syariah menjadi penting bagi masyarakat muslim Indonesia yang disuguhkan dengan keberadaan lembaga keuangan yang mengedepankan norma Islam sebagai sistem operasionalnya, sehingga pengamalan ajaran agama tidak hanya terbatas pada aspek ibadah ritual semata, tetapi aspek muamalah juga dapat diimplementasikan dalam ranah kehidupan social masyarakat, khususnya ranah ekonomi. Sebaliknya, inkonsistensi lembaga keuangan syariah terhadap syariah compliance menciderai Islam sebagai agama yang mengatur aspek kehidupan muslim dalam berbagai dimensi kehidupannya. Karena itu, eksistensi fatwa DSN-MUI akan berjalan efektif apabila didukung dengan metodologi yang tepat dan sesuai dengan karakteristik hukum Islam yang șālị̣ li kulli zamān wa makān, dapat beradaptasi terhadap ruang dan waktu sepanjang zaman.
Bidang ekonomi dan keuangan syariah merupakan medan ijtihad baru karena perkembangannya yang begitu cepat dan masih sedikitnya pendapat ahli fikih tentang masalah ini. Untuk merespon hal ini dilakukan ijtihad jamā'y melalui perumusan fatwa Dewan Syariah Nasional (DSN) MUI. Dalam proses penetapan fatwa ini, DSN-MUI mempergunakan tiga pendekatan, yaitu pendekatan nas qat.' $i$, pendekatan qaūly dan pendekatan manhāji. ${ }^{\text {xiii }}$

Pendekatan nas qat'i dilakukan dengan menelusuri nas-nas al-Qur'an atau hadis yang kualifikasinya mutawātir dan sahih. Apabila kasus yang persoalkan tidak disinggung secara sarih oleh nas al-Qur'an maupun al-hadis, maka proses perumusan fatwa dilakukan dengan pendekatan qaūly dan manhāji. Pendekatan qaūly merupakan teknik penulusuran pendapat imam mazhab secara lintas mazhab dari berbagai aliran untuk menemukan, apakah ada pendapat ulama fikih yang menyinggung kasus yang 
dipersoalkan. Apabila kasus yang dipersoalkan telah ditemukan jawabannya melalui pendapat ahli fikih yang terdapat dalam al-kutūb almu'tabarah (kitab-kitab yang menjadi referensi MUI), maka akan ditempuh proses qiyāsy (analogi), yaitu mencermati apakah 'ilat hukumnya sesuai dengan 'ilat hukum yang ada pada kasus yang dipersoalkan, meskipun hanya terdapat satu pendapat ( $q a \bar{u} \emptyset)$. Dalam kondisi seperti itu, maka fatwa akan memakai pendapat ulama tersebut. Selain proses qiyāsy, akan ditempuh proses I'adah al-nazr (pencermatan ulang) terhadap pendapat yang dianggap tidak dapat dipegangi karena ta'assur atau su'ubah al-'amal (sangat sulit untuk dilaksanakan), atau karena 'ilatnya berubah. Sedangkan pendekatan manhaji, yakni dengan menggunakan metode: al-jam'u wat taüfiq atau tarjīhi digunakan terhadap kasus yang masih dipertentangkan (khilafiyah) di kalangan imam mazhab.

Penetapan fatwa didasarkan pada hasil usaha penemuan titik temu di antara pendapat-pendapat mazhab melalui metode al-jam'u wa al-taūfiq. Namun jika usaha al-jam' $u$ wa altaūfiq tidak berhasil, maka penetapan ditempuh metode tarjihi, yaitu dengan menggunakan metode muqāran almażāhib dengan memperhatikan prinsip-prinsip perbandingan mazhab. Prinsip yang digunakan dalam penetapan fatwa adalah memperhatikan faktor al-arjah dan alaṣlah (valid dan maslahat), karena itu, terkadang penetapan fatwa DSN-MUI yang menurut ulama klasik dasarnya adalah pendapat marjuh (tidak populer), namun karena sesuai dengan kondisi kekinian dan mengandung kemaslahatan, pendapat marjūh tersebut dapat menjadi räjih (unggul dan kuat). ${ }^{\text {xxiv }}$

\section{Pendekatan tarjīh dilakukan} oleh para ulama untuk menentukan kualitas dari dua dalil yang tampak bertentangan secara zahir. Dan sekaligus memutuskan dalil yang pantas untuk diamalkan. Definisi tarjīh menurut Muhammad al-Hafnawi 
adalah: xxv تقديم الجنهد أحد الطريقتين"

المتعارضين لما فيه من مزية معتبرة تجعل العمل به

"karena itu, untuk

menempuh pendekatan tarjīh paling tidak ada beberapa persyaratan yang harus diperhatikan. Pertama, dalildalil yang bertentangan itu dapat diurutkan. Kedua, dalil-dalil yang bertentangan itu memiliki orientasi hukum dan dalam batas kewenangan yang sama. Ketiga, dalil-dalil yang saling bertentangan memiliki kualitas yang sama, baik dari aspek tsubüt, maupun kepastiannya. Keempat, penetapan tarjīh harus didukung dengan argumentasi yang kuat. ${ }^{x x v i}$ Penetapan hukum dengan pendekatan tarjīh yang ditempuh oleh DSN-MUI dalam mencermati dinamika persoalan hukum ekonomi dan keuangan syariah kadang mempertimbangkan persyaratan tarjīh diatas, namun terkadang juga mencermati argumentasi pendukung, seperti, maslahah mursalah, istihsān, sad alżari'ah, dan 'urf. Karena menurut kalangan syafi'I bahwa dibolehkan dalam

proses

tarjīh

mempertimbangkan argumentasi lain untuk mendukung penguatan terhadap suatu dalil yang dianggap kuat dan memiliki kemaslahatan untuk diamalkan.

Dewan Pengawas Syariah merupakan perwakilan DSN-MUI yang ditempatkan di Lembaga Keuangan Syariah (LKS), baik bank maupun non-bank. Ketentuan tentang penempatan Dewan Pengawas Syariah (DPS) pada lembaga keuangan syariah diatur oleh UU Nomor 40 Tahun 2007 Tentang Perseroan Terbatas Pasal 109 dan UU No. 21 Tahun 2008 Tentang Perbankan Syariah Pasal 32 ayat (1). ${ }^{x x v i i}$ DPS memiliki tiga peran penting, yaitu, pertama, sebagai penasihat dan pemberi saran kepada dewan direksi, pimpinan unit usaha syariah, dan pimpinan kantor cabang syariah mengenai hal-hal yang berkaitan dengan kesesuaian operasional lembaga keuangan dengan prinsip-prinsip syariah. Kedua, sebagai pengawas yang memastikan bahwa sistem operasional lembaga 
keuangan syariah tunduk pada ketentuan fatwa DSN-MUI sebagai otoritas penentuan prinsip syariah dalam bidang ekonomi dan keuangan syariah. Ketiga, sebagai mediator antara lembaga keuangan syariah dengan DSN-MUI dalam merekomendasikan pengembangan produk dan layanan jasa lembaga keuangan yang memerlukan fatwa DSN-MUI.

Mencermati fatwa-fatwa DSNMUI, khususnya berkaitan dengan landasan normatif, tampaknya DSNMUI konsisten menerapkan metodologi penetapan fatwa sebagaimana di atas. Seperti penetapan fatwa legalitas multiakad (al-aqd al-murakkabah), kecenderungan fatwa DSN-MUI berpegang pada metode tarjīh. Sumber dalil yang menjadi landasan normatif fatwa DSN-MUI adalah berpegang pada dalil-dalil yang disepakati, seperti al-Qur'an, hadis, ijma', dan qiyas. Selain itu, fatwa DSN-MUI kerap bersandar pada dalil-dalil yang diperselisihkan dikalangan ulama uṣul, seperti istihsān, maslāhah mursalah, 'urf, dan sad al-żari'ah.

(PBI) dan Kodifikasi Produk Perbankan Syariah bersumber dari fatwa DSN-MUI. Kedua sumber hukum tersebut menjadi Standar Operasional Produk (SOP) pada perbankan syariah. Legalitas produk keuangan perbankan syariah harus dilandasi dengan akad. Transaksi keuangan pada perbankan syariah dipandang legimited apabila memiliki alas transaksi, yaitu akad. Ketentuan akad perbankan syariah merupakan ranah hukum yang menggabungkan hukum perikatan Islam dan hukum perdata. Umumnya, fatwa DSN-MUI merupakan transformasi akad-akad dalam hukum Islam ke ranah kegiatan transaksi keuangan modern (almu'amālah al-māliyah al-mu'așirah) seperti perbankan syariah.

Secara sosiologis, kegiatan ekonomi dan keuangan cenderung mengikuti perkembangan dan mengakomodir keinginan masyarakat 
terhadap transaksi keuangannya. Pada sisi yang lain, DSN-MUI, cenderung berpegang pada karakteristik fatwa yang bersifat pasif, yaitu menunggu kasus dan persoalan hukum, kemudian memutuskan solusi hukumnya. Sementara itu, kegiatan ekonomi dan keuangan semakin berkembang dan kompleks, karena itu, dibutuhkan fatwa DSN-MUI yang bersifat responsif, yaitu menemukan solusi baru terhadap transaksi keuangan yang semakin kompleks tersebut.

Produk fikih ekonomi klasik tidak seluruhnya dapat diterapkan dalam konteks waktu dan tempat yang berbeda tanpa memperhatikan kondisi sosio-kultural masyarakat modern sekarang ini. Karena itu, proses ijtihad dan metodologi DSN-MUI yang hanya berdasarkan pada satu disiplin ilmu perlu ditinjau ulang. Sejatinya proses penetapan fatwa DSN-MUI mempertimbangkan disiplin ilmu yang berkaitan dengan ekonomi dan keuangan atau berdasarkan pendekatan interdisipliner dan multidispliner untuk mendapatkan keputusan hukum yang bersifat komprehensif. Pada prinsipnya kegiatan ekonomi dan keuangan merupakan bagian dari aspek mu'amālah yang karakteristiknya

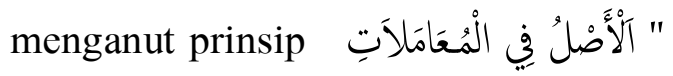

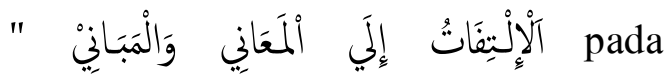
prinsipnya kegiatan mu'amālah memperhatikan subtansi dan illat-nya. Karena itu, hukum muamalah atau ekonomi dan keuangan syariah cenderung mengikuti keinginan masyarakat dan perkembangan kegiatan ekonomi dan keuangan yang berkembang seiring perkembangan transaksi keuangan modern. Namun perkembangan tersebut harus tetap memperhatikan prinsip-prinsip pokok muamalah yang digariskan dalam nas al-Qur' an dan sunah.

\section{KESIMPULAN}

Berdasarkan kajian di atas, dapat ditarik kesimpulan sebagai berikut:

1. Fatwa Dewan Pengawas Syariah memiliki peran 
penting dalam menentukan terimplementasinya prinsipprinsip syariah pada produkproduk lembaga keuangan syariah dan perbankan syariah. Dewan pengawas syariah diakomodir dalam peraturan perundang-undangan di Indonesia. Namun untuk menguatkan fatwa dewan pengawas syariah perlu diangkat statusnya dalam suatu peraturan tersendiri, sehingga rekomendasi yang dihasilkan dapat patuhi dan dijalnkan oleh dewan direksi pada lembaga keuangan syariah dan perbankan syariah.

2. Tantangan yang dihadapi oleh dewan pengawas syariah dalam peningkatan sumber daya manusianya, diantaranya, (a) Sulitnya mendapatkan sumber daya manusia yang memiliki kompetensi dibidang ekonomi dan keuangan syariah. (b) Hasil-hasil rekomendasi kurang mendapat respon dari dewan direksi pada lembaga keuangan syariah dan perbankan syariah.

3. Proses penetapan fatwa ini, DSN-MUI mempergunakan tiga pendekatan, yaitu pendekatan nas qat'i, pendekatan qaūly dan pendekatan manhāji. Pendekatan ini harus dibarengi dengan pendekatan interdisipliner maupun multidisipliner agar fatwa dewan syariah nasional memiliki kekuatan hukum yang pasti. 


\section{Daftar Pustaka}

\section{Bibliography}

Amin, Ma'ruf, Pembaruan Hukum Ekonomi Syariah dalam Pengembangan Produk Keuangan Kontemporer (Transformasi Fikih Muamalah dalam Pengembangan Ekonomi Syariah), Naskah pidato Ilmiah pada Penganugerahan Gelar Doktor Kehormatan dalam Bidang Hukum Ekonomi Syariah pada Rapat Senat Terbuka UIN Syarif Hidayatullah Jakarta, 2012,Manhaj Fatwa, (makalah yang disajikan pada acara Annual Meeting DPS di Bogor), September 2006

Amin, Abd. Rauf, al-Ijtihad Ta'aśsarahu wa ta'sirhu fi Fiqhi al-Maqāsid wa al-Waqi', Cet. I; Beirut: Daar al-Kutub al-Ilmiyah, 2013

Amin, Muhammad Suma, Himpunan Undang-undang Perdata Islam dan Peraturan Pelaksanaan Lainnya di Negara Hukum Indonesia, cet. I; Jakarta: PT RajaGrafindo Persada, 2004

Anwar, Syamsul, Hukum Perjanjian Syariah, Studi tentang Teori Akad dalam Fikih Muamalah, Cet. I; Jakarta: PT. RajaGarafindo Persada, 2007.

'Azzam, Abd. Aziz, al-Qawāid alFiqhiyah, Cet. I; Kairo: Dār alHadis, 2005

Badan Nasional Sertifikasi Profesi (BNSP), Pedoman Penyusunan
Kompetensi Kerja, Jakarta, 2005

Bank Indonesia, Peraturan Bank Indonesia Nomor 11/33/PBI/2009 Tentang Pelaksanaan Good Corporate Covernance bagi Bank Umum Syariah dan Unit Usaha Syariah, Situs Resmi Bank Indonesia, $\quad$ www.bank Indonesia.com

Majelis Ulama Indonesia, Himpunan Fatwa MUI sejak 1975, Cet. II; Jakarta: Erlangga, 2011

Marwansyah, Manajemen Sumber Daya Manusia, edisi II, cet. II; Bandung: Alpabeta, 2012

Muhammad, Ali Jum'ah, Maūsū'ah alIqtsad al-Islämi fi alMașarif wa al-Nuqūd wa alAswāq al-Māliyah, Jilid. III, Cet. I; Kairo: Daar alSalām, 2009.

Nafis, M. Cholil, Teori Hukum Ekonomi Syariah, Kajian Komprehensif Tentang Teori Hukum Ekonomi Islam, Penerapannya dalam Fatwa Dewan Syariah Nasional dan Penyerapannya ke dalam Peraturan Perundangundangan , Cet. I; Jakarta: UI Press, 2011.

Rusdi, Muhammad Ali. Maslahat Sebagai Metode Ijtihad Dan Tujuan Utama Hukum Islam. DIKTUM: Jurnal Syariah dan Hukum, 2017, 15.2: 151-168.

Otoritas Jasa Keuangan (OJK),

"Statistik Perbankan Syariah", Situs

Resmi OJK. www. OJK. go.id. 3

April 2013. 


\section{Catatan Akhir}

'Otoritas Jasa Keuangan (OJK), "Statistik Perbankan Syariah", Situs Resmi OJK. www. OJK. go.id. (3 April 2014).

${ }^{\mathrm{ii}}$ M. Cholil Nafis, Teori Hukum Ekonomi Syariah, Kajian Komprehensif Tentang Teori Hukum Ekonomi Islam, Penerapannya dalam Fatwa Dewan Syariah Nasional dan Penyerapannya ke dalam Peraturan Perundang-undangan, Cet. I; Jakarta: UI Press, 2011, h. 81. Lihat, juga Pedoman Dasar Dewan Syariah Nasional Mejelis Ulama Indonesia, Surat Keputusan Dewan Syariah Nasional-Majelis Ulama Indonesia Nomor 01 Tahun 2000 Tentang Pedoman Dasar Dewan Syariah NasionalMajelis Ulama Indonesia, bagian 2,3 dan 4.

iii Surat Keputusan Direksi Bank Indonesia No. 23/34/1999 Pasal 31 berbunyi: "untuk melaksanakan kegiatankegiatan usahanya, bank umum syariah diwajibkan untuk memperhatikan fatwa DSNMUI. Demikian pula dalam hal bank akan melakukan kegiatan usaha sebagaimana dimaksudkan dalam Pasal 28 dan 29 jika ternyata kegiatan usaha yang dimaksudkan belum difatwakan oleh DSN, maka bank wajib meminta persetujuan DSN sebelum melaksanakan usaha kegiatan tersebut".

${ }^{\text {iv} P a s a l ~} 109$ Undang-undang No. 40 Tentang Perseroan Terbatas berbunyi: "(1) Perseroan yang menjalankan kegiatan usaha berdasarkan prinsip syariah selain mempunyai Dewan Komisaris wajib mempunyai Dewan Pengawas Syariah. (2) Dewan Pengawas Syariah sebagaimana dimaksud pada ayat (1) terdiri atas seorang ahli syariah atau lebih yang diangkat oleh RUPS atas rekomendasi Majelis Ulama Indonesia. (3) Dewan Pengawas Syariah sebagaimana dimaksud pada ayat (1) bertugas memberikan nasihat dan saran kepada Direksi serta mengawasi kegiatan Perseroan agar sesuai dengan prinsip syariah.

${ }^{v}$ Majelis Ulama Indonesia, Surat Keputusan Dewan Syariah Nasional-Majelis Ulama Indonesia No. 02 Tahun 2000 Tentang
Pedoman Rumah Tangga Dewan Syariah Nasional-Majelis Ulama Indonesia Pasal 2

${ }^{\mathrm{vi}}$ Majelis Ulama Indonesia, Surat Keputusan Dewan Syariah Nasional-Majelis Ulama Indonesia No. 02 Tahun 2000 Tentang Pedoman Rumah Tangga Dewan Syariah Nasional-Majelis Ulama Indonesia Pasal 2

vii Pedoman Penetapan Fatwa Majelis Ulama Indonesia, Nomor: U-596/MUI/X/1997

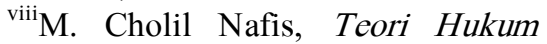
Ekonomi Syariah, h. 92-93

${ }^{\mathrm{ix}}$ Muhammad Amin Suma, Himpunan Undang-undang Perdata Islam dan Peraturan Pelaksanaan Lainnya di Negara Hukum Indonesia, cet. I; Jakarta: PT RajaGrafindo Persada, 2004. Pasal 32 ayat (1) UU No. 21 Tahun 2008 Tentang Perbankan Syariah menyebutkan bahwa "Dewan Pengawas Syariah wajib dibentuk di bank syariah dan bank umum konvensional yang memiliki unit usaha syariah".

${ }^{\mathrm{x}}$ Bank Indonesia, Peraturan Bank Indonesia Nomor 11/33/PBI/2009 Tentang Pelaksanaan Good Corporate Covernance bagi Bank Umum Syariah dan Unit Usaha Syariah, Situs Resmi Bank Indonesia, www.bank Indonesia.com (5 Agustus 2014)

${ }^{x i}$ Badan Nasional Sertifikasi Profesi (BNSP), Pedoman Penyusunan Kompetensi Kerja, (cet. Jakarta, 2005), h. 2

xii Marwansyah, Manajemen Sumber Daya Manusia, edisi II, cet. II; Bandung; Alpabeta, 2012, h. 36

xiii Secara formal, Kompetensi DPS diatur dalam PBI No. 11/3/PBI/2009 Tentang Bank Umum Syariah Pasal 34 ayat (2) bagian b, yaitu: "Kompetensi DPS paling kurang memiliki pengetahuan dan pengalaman di bidang syariah mu'amalah dan pengetahuan di bidang perbankan dan/atau keuangan secara umum".

xiv Ali Jum'ah Muhammad, Mausu'ah al-Iqtșad al-Islami fi al-Masarif wa al-Nuqūd wa al-Aswāq al-Māliyah, Jilid VII, h. 296

${ }^{x v}$ Ali Jum'ah Muhammad, Mausu'ah al-Iqtiṣād al-Islāmy fi al-Mașārif wa al-Nuqūd wa al-Aswāq al-Māliyah, Jilid VII, h. 270 
${ }^{\text {xvi }}$ Ali Jum'ah Muhammad, Mausu'ah al-Iqtisāàd al-Islamy fi al-Mașārif wa al-Nuqūd wa al-Aswāq al-Māliyah, Jilid VII, h. 271

${ }^{x v i i}$ Undang-undang Perbankan

Syariah No. 21 Tahun 2008 Pasal 64 menyebutkan bahwa "Pihak Terafiliasi yang dengan sengaja tidak melaksanakan langkahlangkah yang diperlukan untuk memastikan ketaatan Bank Syariah atau Bank Umum Konvensional yang memiliki UUS terhadap ketentuan dalam UU Perbankan Syariah dipidana dengan pidana penjara paling singkat 3 (tiga) tahun dan paling lama 8 (delapan) tahun dan pidana denda paling sedikit Rp. 5.000.000.000.00 (lima miliar rupiah) dan paling banyak Rp. 100.000.000.000.00 (seratus miliar rupiah).

xviii Ali Jum'ah Muhammad, Mausu'ah al-Iqtiṣād al-Islāmy fi al-Mașārif wa al-Nuqūd wa al-Aswāq al-Māliyah, Jilid VII, h. 252

xix Ali Jum'ah Muhammad, Mausu'ah al-Iqtiṣād al-Islämy fi al-Masăàif wa al-Nuqūd wa al-Aswāq al-Māliyah, Jilid VII, h. 254

xx Ali Jum'ah Muhammad, Mausu'ah al-Iqtisāàd al-Islāmy fi al-Mașāin wa al-Nuqūd wa al-Aswāq al-Māliyah, Jilid VII, h. 255

${ }^{x x i}$ UU Perbankan Syariah Pasal 26 ayat (3) dan (4) menyebutkan bahwa: "Fatwa DSN-MUI dituangkan dalam Peraturan Bank Indonesia" "Dalam rangka penyusunan Peraturan Bank Indonesia sebagaimana dimaksud pada ayat (3), Bank Indonesia membentuk Komite Perbankan Syariah”.

$$
{ }^{x x i i} \text { Pasal } 35 \text { PBI No. }
$$

11/3/PBI/2009 berbunyi: "DPS bertugas dan bertanggungjawab memberikan nasihat dan saran kepada Direksi serta mengawasi kegiatan Bank agar sesuai dengan Prinsip Syariah. (2) Pelaksanaan tugas dan tanggung jawab DPS sebagaimana dimaksud pada ayat (1) meliputi antara lain: (a) menilai dan memastikan pemenuhan Prinsip Syariah atas pedoman operasional dan produk yang dikeluarkan Bank. (b) mengawasi proses pengembangan produk baru Bank. (c) meminta fatwa kepada Dewan Syariah Nasional untuk produk baru Bank yang belum ada fatwanya. xxiii Ma'ruf Amin, Manhaj Fatwa, (makalah yang disajikan pada acara Annual Meeting DPS di Bogor), September 2006, h. 7 ${ }^{\text {xxiv }}$ Ma'ruf Amin, Manhaj Fatwa, (makalah yang disajikan pada acara Annual Meeting DPS di Bogor), September 2006, h. 7 ${ }^{x x v}$ Tarjīh adalah seorang Mujtahid medahulukan salah satu dari dua dalil yang bertentangan karena ada keunggulan yang diakui sehingga menjadikan dalil tersebut lebih pantas untuk diamalkan ketimbang dalil lainnya.

h. $296{ }^{\text {xxvi }}$ Hafnawi, al-ta'arud wa al-tarjih, Tahun 2008 Tentang Perbankan Syariah menyebutkan bahwa "Dewan Pengawas Syariah wajib dibentuk di bank syariah dan bank umum konvensional yang memiliki unit usaha syariah". 